\title{
Digital Books For Educational Communication
}

\author{
Farida Febriati ${ }^{1}$, Citra Rosalyn Anwar ${ }^{2}$, Apriliyani afilyah Saba ${ }^{3}$ \\ \{Ida.febriati@gmail.com ${ }^{1}$, citrarosalynanwar@gmail.com ${ }^{2}$ \} \\ 1,2,3 Teknologi Pendidikan, Universitas Negeri Makassar. Makassar, Indonesia
}

\begin{abstract}
The technology that moving so fast, forces every dimension of life to move quickly too, including in education process. The need for teaching materials as part of the teaching-learning process, which so far still refers to textbooks no longer attracts the attention of students. Even though there are online journals or websites, unverified articles are still the choice for students, because that showing fast in Search Engine. These conditions require creativity for lecturers. Communication of Education is one of the basic subjects of students to learn, but it has limitations face to face class because there are a lot materi. The ability of this flipbook-based digital book is considered the right choice because it not only offers text, but also images and videos, without internet connection. This article describes the process of student admission to a Flipbook-based digital book that was developed as a teaching material for Communication education Courses at Education Technology Study Program, Faculty of Education,University negeri Makassar. This article is a qualitative descriptive study, the main data source was obtained through in-depth interviews with several students based on Purposive techniques, questionnaires and direct observation in Communication Education class during the teaching and learning process. The results of the study showed the enthusiasm of students in using flipbook-based digital books as teaching materials for Communication Education courses. This is a new thing in the Educational Technology Study Program, students consider this flipbook-based digital book offers more convenience than ordinary textbooks, such as being easier to carry, there are tutorial videos, colorful sheets, images can be zoom and free.
\end{abstract}

Keywords: Coomunication, Digital books, students, education. technology

\section{Introduction}

Education Communication in the Study Program of Educational Technology, Faculty of Education Universitas negeri Makassar, so far it is quite difficult to get references as supporting material in the class. That is because the general reference as a major study communication, there is not speciality in educational communication. Whereas learning resources are important to facilitate the learning process (Dale in Sitepu 2014: 18). Education Communication class are compulsory courses given to new students in educational technology. Communication Education itself is actually a development of Communication Science. Communication skills are abilities that are needed by every human being, because there is almost no activity without communication. One Cannot can't communicate (Watzlawick). The ability to develop and use technology without being balanced by communication skills, will become an incomplete competency. Likewise, knowledge no matter how broad or deep a person's knowledge is if it is not balanced with the ability to communicated it, then that knowledge will not be accept to the public.

Educational communication has a lot of material that is not all delivered in one semester meetings, this situation become encourages for researchers to develop teaching materials and package them in the form of digital books based on Flipbook. In era digitalization and the current phenomenon of students prefer to use gadgets in their daily activities rather than 
carrying textbooks. Eventhough digital books are the right choice to use in the learning process in multimedia learning subjects. This is based on studies that have been there before (Mawarni and Muhtadi: 2016), digital books are good to trying to the multimedia subject.

The existence of textbooks as teaching material is considered only able to provide theoretical understanding, without providing practical practice facilities, it is obtained from the results of preliminary observations, besides books are considered monotonous, less practical, and less suitable for learning skills that require practice. Along with the times, books have been integrated with electronic devices as a development of new technology, namely e-books (electronic books).

E-books (digital books) are one example of a combination of the use of electronic technology (smartphones, laptops, notebooks) with textbooks, so that people can read books in the form of soft files that are equipped with images that can be enlarged, and are easy to carry. E-books are like moving a display of a textbook into electronic devices, such as smartphones and laptops. Now began to be developed types of digital books that emphasize more on the aspects of interaction and the integration of media content. Digital book content can consist of a combination of text, graphics, animation, sound and video tutorials in one device.

This digital book can be an appropriate source of learning for Education Communication courses, because the material can be conveyed more clearly in addition to material in the form of text and illustrative images. The limited time in class can be overcome through the presentation of text and images that can be studied independently by students.

Sella Mawarni and Ali Muhtadi (2017) in their research showed that digital books are an effective choice used in the learning process in multimedia learning courses in the Educational Technology study program at the Faculty of Education, Universitas negeri Yogyakarta. In addition to open access, ejournal, articles or e-libraries, there are many learning resources that are now available online, not only that books are then integrated with electronic devices as a development of new technologies, namely e-books (electronic books). E-books or electronic books are one example of a combination of the use of electronic technology (smartphones, PCs, notebooks) with textbooks, so reading books in the form of soft files that are equipped with enlarged images, video tutorials, are easy to carry. E-books are like moving a display of a textbook into electronic devices, such as smartphones and PCs. To develop types of digital books that emphasize more on the aspects of interactivity and the integration of media content. Digital book content can consist of a combination of text, graphics, animation, sound and video in one device. Digital books more than just books in electronic versions, with various types of digital information in the form of text, images, audio, video that can be opened through computers, tablets, and smartphones.

Books as a source of teaching materials, increasingly experiencing a shift with the presence of digital technology. Students are increasingly facilitated by the many learning resources available online. The problem with online learning resources are not every students are able to choose appropriate and valid learning resources, because in addition to eJournal, there are also many blogs whose anonymous authors, so the subject is certainly not entirely trustworthy. Teaching materials must also be in accordance with the needs of the user and the situation faced by the user, in other words, the textbook as the main teaching material needs to be owned by each lecturer, because it adapts to the situation and conditions of the lecture.

Digital books are an alternative multimedia-based teaching material, digital book development can use several applications, Flipbook is one application that can be used for the development of digital books. This flipbook was chosen, because it has features that resemble conventional textbooks, where the sheet can be opened like a textbook. 
Digital books according to Gardiner, et al, (2010) in Prasetya (2015) says, digital books are publications of books in digital form, consisting of text, images, or both, and are easy to read on computers or other electronic equipment.

Digital books are publications in the form of text and images in digital form that are produced, published, and can be read through computers or other digital devices (Andina 2011; 119-146). In this era Digital book display design much in demand by the public is a digital book with three-dimensional ebook technology known as a flipbook, where pages can be opened like reading a book on a monitor screen. The publication in the flipbook that is commonly used is .exe so users must install supporting software in the form of Adobe Flash Player. Fitriyawan (2015: 2)

Flipbook is one of the software that used to make digital books. This flipbook software is a computer program that has the ability to display multimedia, a combination of graphics, text, animation and video into the display of a book in swf format. Presetya (2016: 61-62) describes that now there are many digital book formats that can be found, three of which are very popular are PDF, AZW, and ePub. PDF (Portable Document Format) is the oldest and most used digital book format. Flipbooks offers to load files in the form of text, moving images or animations and videos.

Digital books that are equipped with a variety of learning content, ranging from text, images to video tutorials are the right learning resources for Education Communication courses. Material about education communication can be conveyed more clearly with the additional content in the form of pictures and text, in addition to material in the form of text and illustrative images. This book is digital based, so students can use it via a laptop or smartphone making this digital book a learning resource for students that is easy to use anytime and anywhere.

This article provides an overview of how students accept this flipbook-based digital book as a reference source of teaching materials in the Communication Education course in the Educational Technology Study Program, Faculty of Education, Universitas Negeri Makassar. Although digital books already used before, but in the learning process at the Educational Technology Study Program at the Faculty of Education UNM, digital books were introduced and used first time for Sinematography courses for the academic year 2017/2018, and Communication Education 2018/2019.

Previous research conducted by Mawarni and Muhtadi (2016) Development of Interactive Digital Books for Interactive Learning Multimedia Development Courses for Educational Technology Students, and Nurhayati (2017), Development of Interactive Digital Books for Development of E-Learning Subjects in FIP UNY Educational Technology Students describe that Digital book is one of the effective and interesting media used in the learning process in multimedia-based subjects. Other research conducted by Hendra saputra and Citra Rosalyn Anwar (2018), entitled Digital books, textbooks that tell stories, were published in Uniga journals ${ }^{1}$.

All of Those studies, based on development research, which although different but somewhat have similarities with this research, research conducted by Sella Mawarni and Ali Muhtadi (2016), puts the focus on multimedia courses, while research conducted by Dian Nurhayati ( 2017) in Elearning learning courses. Hendra Saputra (2019), in the Cinematography course, but the focus is on developing teaching materials in the form of digital books based on flipbooks as teaching materials. In addition, the three previous studies focused on interactive teaching materials, where interaction between readers can directly

${ }^{1}$ https://journal.uniga.ac.id/index.php/JK/article/view/592 
occur through discussion forums, and tests in accordance with the subjects they study, namely multimedia, e-learning and cinematography, which makes this research become different because there are no tests and discussion forums, but rather presents the text because it is in accordance with the subject of Communication Education, so this article naturally puts more focus on the description of the acceptance of educational technology students at the Faculty of Education UNM as users of this digital book in the Communication course Education.

This is interesting, because digital books in educational communication courses, where the main material is theory, is different from the cinematography which is more project based, so video tutorials and photos can be utilized fully. Previous studies like this were more focused on developing teaching materials, in contrast to the focus of this study which prefers to describe student acceptance in this flipbook-based digital book as a reference source of teaching materials in the Communication Education course.

Based on data from preliminary observations, for students who first used digital books as teaching materials in cinematography courses, students expressed their enthusiasm to use digital books as teaching materials. The enthusiasm is because the digital book has a different appearance from the text books or modules that were previously used, with various facilities such as video tutorials, images can be enlarged and reduced, easy to carry.

\section{Method}

The research location are in the Educational Technology Study Program (Prodi), at students who program Communication education courses. Research time adjusts to time when the course is taught, at semester 2017/2018. Research informants were selected using purposive sampling method,that is, from students who program this course, 5 are chosen Research informants were selected using a purposive method. Research took place in the Educational Technology Study Program, Educational Communication courses, because in addition to meeting the needs of teaching materials, also the main material of educational communication which is more theory than practice is different from other project-based courses. The time of the study adjusts to the time when the course is taught, ie even semester $2018 / 2019$.

Research informants were selected using a purposive method, ie from students whprogramed this course, 5 (five) students were selected in accordance with the criteria set by theresearcher namely, students who had just taken the Educational Communication Course, had not used a previous digital book, representing students male and female, and most show enthusiasm when this flipbook-based digital book is used.

Tabel 1. Informant

\begin{tabular}{|c|c|c|c|}
\hline No 1 & $\begin{array}{l}\text { Name(pseudonym) } \\
\text { Gender }\end{array}$ & & \\
\hline & 1. Dina & 20 & Female \\
\hline & 2. Hera & 20 & Female \\
\hline & $\begin{array}{ll}\text { 3. } & \text { Ferdi } \\
& \text { Male }\end{array}$ & & \\
\hline & $\begin{array}{ll}\text { 4. } & \text { Alam } \\
\text { Male }\end{array}$ & & \\
\hline & $\begin{array}{ll}\text { 5. } & \text { Mita } \\
\text { Female }\end{array}$ & & \\
\hline
\end{tabular}

Email : icest@unm.ac.id. 
Data collection based on observation and interviews. First, observations were made in the classroom then through Whatsapp Group social media which included a description of students on digital books especially those based on Flipbooks, experiences using digital books, Communication Education courses and prior teaching materials. Next, arrange an interview schedule either in person or through the Whatsapp messaging feature. The interview topics included views on Education Communication courses and Flipbook digital books. Enthusiasm, advantages and disadvantages of this flipbook-based digital book for education communication courses.

The analysis process begins by collecting data from interviews and observational notes in the field (field notes) and then transcribing the data. The data collected is categorized based on themes that emerge from the results of observations and interviews, namely digital books based on flipbooks, the process of using digital books for Education communication courses, interesting things from this digital book, the advantages and disadvantages of digital books as teaching materials and how to overcome deficiencies. The next process is then followed by coding data based on emerging themes. Before conducting an interview, the informant first had to explained about the aims and benefits of the study and asked willingness to be an informant in this study, while reminding the participation will not affect the score of this educational communication course . After agreeing, the researcher requested permission to record the interview process carried out to facilitate the writing process

In this study, based on the accuracy with the informants, the names used are pseudonyms. To maintain the confidentiality of the informant's identity and the information provided. Informants are determined to be interviewed according to established criteria, based on classroom observations and preliminary data held before starting the development of this digital book. Interviews took place several times, during the lecture process, where flipbookbased digital books were used.

\section{Educational Communication}

Communication according to Michael Motley (1990) only occurs if the message was intentionally directed at someone else and received by the person in question. whereas according to Peter Anderson (1991) Communication must include every attitude that gives meaning to the recipient, regardless of whether that meaning will be noticed or not. Communication is a social process where individuals use symbols to create and interpret meaning in their environment, the five key terms in this perspective are social, process, symbol, meaning and environment (West \& Turner 2009; 5). Pace and Faules state that there are two general forms of action taken by people involved in communication, such as the creation of messages and the interpretation of messages. The message here does not have to be in the form of words, but can also be a appearance, including clothing, jewelry and facial expresssion or what is commonly called a nonverbal message or body language. Reading a book can be said are communicate, because the researcher or author tries to convey a message to the reader (in Mulyana 2008; 65).

There are so many definitions of communication that Fisher (1986) cited by Arifin (1988; 25) groups them into five categories of definitions that they have found, (1) definitions that focus on delivery or passage, (2) definitions that place communication as social control (3) definition which emphasizes the element of togetherness of meaning and (5) definition which sees communication as a social integrator.

After discussing communication, it is necessary to propose the concept of education. Simply according to the Indonesian Dictionary (KBBI) is the process of changing the attitudes and 
behavior of a person or group of people in an effort to mature humans through teaching and training efforts. This understanding gives meaning that education is a process, method and act of educating. The Father of Indonesian National Education, Ki Hajar Dewantara (1889-1959) explained about the nation of education,which is: "Education generally means the effort to advance character (character, inner strength), mind (intellect) and physical bodies of children in harmony with nature and society. "

Frietz R. Tambunan (2004) in an article said, the word education comes from the Latin word educare literally means "pulling out of" so that education is an act of bringing a student out of the condition of not being independent, immature, and dependent, a situation independent, mature, can determine themselves, and responsible. Education in a policy perspective, we have formal and operational formulations, as stipulated in Law No. 20 of 2003 concerning SISDIKNAS,: Education is a conscious and planned effort to create an atmosphere of learning and learning process so that students actively develop their potential to have religious spiritual strength, self-control, personality, intelligence, noble character, and the skills needed by themselves, society, nation and country.

Education is not just transferring knowledge (transfer of knowledge) to students but more than that, transferring value (transfer of value) besides education is also a cultural work that requires students to always develop their potential and creativity to keep surviving in his life.

Paulo Freire, is one of the education leaders who is called the hero of critical education. Freire underlines that in the world of education there are three main elements, namely instructors, students and world realities, where the relationship between the first and second elements as well as friends, complement each other in the learning process. This is certainly contrary to "bank style education", where teachers are placed in the top position, so students must be positioned below by accepting the pressures of the instructor's authority. Such education will only give birth to oppression and not in accordance with nature. Education should be understood as a series of renewal efforts. Education in essence does not end because human quality continues to improve.

The interrelationsips Study and communication events that occur in education, such as how to communicate, what is used, through what, where, why and who is communicating. The relationship between communication and education is mutually influencing or reciprocal. How education affects communication in a simple way, can be seen in the choice of sentences, appearance, way of speaking, and so on, influenced by one's educational background. Education Communication Studies are not as popular as other communication studies, such as political communication or health communication. Therefore it is important to make it a study material, given the role of communication in education.

In general, what is meant by educational communication is the domain of communication associated with education. as well as health communication, political communication and so forth. There are two basic considerations that are important to consider to understand the importance of educational communication. (1) education world really needs a holistic, comprehensive, fundamental and systematic understanding of the use of communication in the implementation of teaching and learning activities. (2) educational communication will show the direction of the social construction process of the reality of educators as one of the perpetrators of educational activities.

Communication clearly also occur in the context of education, but often in the world of education this is not the main concern. Naim (2011: 7) revealed that there were still teachers who ignored communication methods in the world of education or did not realize that what they delivered to students greatly influenced students' perceptions, interests and motivation in absorbing knowledge. 
The concept of education itself proposed by Paulo Freire and John Dewey, emphasizes communication as a major element in education. Freire emphasizes the model of the relationship between educators and students that runs in a dialogical and participatory way, the dialogic education that is conceived by it matches the dialectical dynamics between educators and students.

\section{Teaching materials}

a) Learning material or material is the substance that will be taught in learning activities. Thus learners must master the learning material well. There are three main issues related to mastery of learning materials, namely mastery of the subject matter, description of the material, and supplementary material.

b) The main material is learning material taught by learners. Material description is the breakdown of subject matter, as well as sub-material. While supplementary material is the supporting material needed in learning to open up insights in supporting the delivery of the subject matter. Supporting material is usually sourced from different disciplines from the subject matter.

c) Teaching materials have different terms given by experts. According to Darwin Syah, et al (Sumantri, 2015: 328) "teaching material is one source of learning that contains messages in forms: concepts, principles, definitions, context, data, facts, processes, values and skills". Furthermore, Newby, et al (Yaumi, 2013: 244) provide a definition of teaching materials by saying that "instructional materials are the specific items used in lessons and delivered through various media". Which means teaching material is a special material in a lesson delivered through various media.

d) Based on the opinions as described above, what is meant by teaching material is a set of materials that are arranged systematically so as to create an atmosphere of learning process. teaching materials can be divided into five types, namely:

e) Teaching material that is not projected is teaching material that does not require the projector to project the contents inside. Students can directly use (read, see, observe) the teaching material. Example: photos, diagrams, displays, and models.

f) Projected teaching material is teaching material that requires a projector to be used by students. Example: slides, filmstrips, transparent overhead, computer projection.

g) Audio teaching material is teaching material in the form of audio recording recorded in a recording media. Example: cassette, $\mathrm{CD}$, and flash disk.

h) This video teaching material requires a player which usually takes the form of a video tape player, VCD player, and DVD player. Because this teaching material is almost similar to audio teaching material. But the difference is there are teaching material images. So, simultaneously in the display can be obtained by a picture and sound presentation. Example: video and film.

i) Computer media materials are various types of non-printed teaching materials that require computers to display something to learn. Example: Mediated Instruction (CMI) and Computer Based Multimedia or Hypermedia.

\section{Digital Book}

Digital books according to Andini (2011) "are publications in the form of text and images in digital form that are produced, published, and can be read through computers or other digital devices". The same thing is written in the English Dictionary which is a member of the term E-book in the electronic version of the book. E-book is an abbreviation of Electronic 
book, is a form of book that can be opened electronically through a computer. While interactive itself is defined as the activities of mutual interaction (going both ways) between the media and those using media (users).

Digital book display design now with three-dimensional e-book technology known as flipbooks, where pages can be opened like reading a book on a monitor screen (Riyanto, et al. 2012). Flipbooks are being developed for learning in schools. Research conducted by Ramdania, et al. (2007) says that the use of flipbook media in learning can improve student learning outcomes. This is influenced by students' interest in their appearance which is more interesting and interactive than printed books. This latest technology provides a great opportunity for the use of digital books in science and distance learning (Gorghiu, 2011). According to Shidieqy and Lestari (2010) the things needed in the development of digital books as teaching material, learners, facilities and learning media, facilitators (teachers), and the availability of evaluation.

\section{Flipbook}

Flipbook is known as PDF Professional, this Flipbook Software can make PDF to HTML5 or flash with 3-dimensional flipping animation that can be seen from various devices such as computers / android. Flipbook can also be referred to as a multimedia-based electronic book maker software. Flipbooks can load files in the form of text, moving images or animations and can load videos. In use there are interactions between the media and those who operate them. The interaction is the user's activity in playing the video and turning the page as the user wants. Thus fllipbook can be said as interactive multimedia.

Add multimedia to PDF pages in simple ways, such as adding text, hyperlinks, videos (including videos from YouTube), Flash movies, images, hotspots, clipart, and sounds to enrich flipbook PDF pages. This will be a good tool to enhance PDF reading experience .

The advantages of flipbooks are that they are easy to use, there are also various button features, interesting animations for students, besides flipbooks are also able to load videos that can be used as listening teaching and learning material so that students find it easier to understand material that can be used through projection tools such as computers, tablets or android. But of course the flipbook also has shortcomings namely in classical learning digital book projection tools such as computers / laptops must be adequate with the number of students.

\section{Results and Discussion}

\section{Digital Book, Simple and Communicative}

One of the obstacles felt in the learning process, is that it is difficult for students to buy reference books, the recognition they propose that in addition to being limited in funds, the Internet also offers quite a lot of references. That is why digital-based teaching materials are certainly not new, web, blogs, e-journals and so on for students because they have long been used as a complement or reference. However, digital books are used as teaching material, substitutes for textbooks in the Education Technology Study Program itself are only used for Cinematography courses. This digital book is also interesting in addition to this new thing also because it was developed by the teaching team of the Cinematography course of educational technology itself, based on needs analysis, and the process of developing teaching materials that were implemented before the digital book was introduced to students in the classroom. 
The enthusiasm of students was very high when they were first introduced to this digital book, they downloading to their laptops, asking lots of questions about how digital books were used, and trying out various tools, discussions and even continuing outside the classroom, both directly and through the chat application. This is understood mainly because this is their first digital book and was developed by a team supporting this course. Although students are familiar with online teaching materials, in their opinion, digital books are more interesting than the web or blog. Dina (20 years) stated that this digital book is interesting, because it is different from other teaching materials, full color. The picture can be zoomed in, there is even a video tutorial feature, so it doesn't bore you.

Mita (20 years), expressed interest in reading digital books in addition to being new, the sheets because the chapters and material were distinguished by color, the video tutorial was only played and the image was enlarged. The new way to read this book, also revealed by Alam (20 years), according to him, reading on a laptop is easier, easy to use, and the tutorial is just a click away.

The opinion of the informant above shows the interest of students by using interesting and communicative words, this Digital Book based on flipbook is interesting to be interpreted by students because in addition to being new, not only in the form of text, but also video tutorials that can be directly rotated, colorful sheets, images that can be zoomed in and because the creator is a team of lecturers who also teach courses in communication, thus facilitating the discussion process.

This flipbook-based digital book, have an interesting appearance, also offers the convenience of being obtained because it does not incur costs, or internet quota, so it does not add burden to students. This was revealed by Ferdi (20 years) who says that this digital book was easy to obtain, cheap and communicative to understand.

Alam (20 years), illustrates the ease of obtaining and using this digital book, that aside from being free, without quota, can be read at any time, anywhere and can even discuss if there is something that is not understood, or that you want to know about the manufacturing process, not just the contents Education Communication course material.

The most interesting feature according to Dina (20 years) is because it makes it easy for students to remember the limited class time meeting, Another convenience of digital books based on flipbooks, is that they do not require an internet connection, because when they trying to read at online journals or the web, in addition to requiring data quotas also often actually break up the concentration of students when searching material for assignments, usually their attention is divided by other things, such as online games, YouTube social media and so on. This digital book because not require an internet connection, makes students more focused when studying and reading it. Alam (20 years) stated that there was a lot of temptation when connected to the internet, not just working assignments, reading journals but instead opening social media, watching movie, chatting, playing games, and others.

Digital books downloaded on laptops are not only cheap but also easy for students because they do not have to carry a large number of printed textbooks or modules. Mita (20 years), stated that as a student who always carries a laptop, adding books or modules is just difficult.

\section{Weaknesses of Digital Books}

Various advantages expressed by informants as users of digital books, such as easy because they do not have to carry textbooks, interactive, communicative to tools that are easy to use. Cheap, because only copying files to each laptop is free and does not require internet 
quota. Interactive, does not need the internet so it can be read any time, not affected by social media, chat, and so on.

Strengths and conveniences obtained by students, especially in the process of lecturing in educational communication, this flipbook-based digital book, has weaknesses. Weaknesses revealed by the informant which is, (1) can only be used via a laptop, (2) does not have a page (3) no highlighting facilities, (4) eyes get tired easily.

Smartphone usage requires special applications, and large memory. This causes informants to choose to keep using only the laptop. This was revealed by Mita (20 years), Hera (20 years and Ferdi (20 years), they stated that if it could be opened on a smartphone, the reading process would be easier, because they could read while waiting for lectures in the canteen, in public transportation, and so on, while laptop requires its own space, a weakness that is also considered quite disturbing is the lack of tools to highlight or mark important sentences Dina (20 years) states cannot highlight or mark important parts as such, in printed textbooks, or journals -journals online, even though the highlights are useful for reminding important information without having to read it again in its entirety.

These statements provide an illustration, with the various advantages offered by this digital book, apparently leaving a problem that is quite disturbing for the informants. Even so informants, they still consider the weaknesses or weaknesses of this digital book they can still accept, because the convenience of digital books is far more useful for them.

\section{Conclusions}

The various advantages possessed by this digital book are communicative and interesting. free and without internet quota, and fun. Deficiencies such as can only be used via a laptop, do not have a page, there are no highlighting facilities, and eyes get tired easily, does not reduce the enthusiasm of student users to read and use this digital book. This shows the need to make digital books as alternative references or teaching material.

\section{References}

Andina, E. 2011,"Buku digital dan pengaturannya”. Aspirasi 2(1):119-146

Fitriyawan. 2015. Buku Digital Multimedia Berbasis Flip Book Maker pro dalam Meningkatkan Minat Baca Siswa (Studi Kasus pada Mata Pelajaran Sejarah Kelas XI SMA Candiroto).Skripsi, Jurusan Teknologi Komputer Universitas Kristen Satya wacana,

Mawarni, Sella dan Ali, Muhtadi. 2017. "Pengembangan Digital Book Interaktif Mata Kuliah Pengembangan Multimedia Pembelajaran Interaktif Untuk Mahasiswa Teknologi Pendidikan: Jurnal Inovasi Pendidikan, (Online), Vol.4 No.1. Diakses 22 Januari 2018.

Nurhayati, Dian. 2017. Pengembangan Buku Digital Interaktif Mata Kuliah Pengembangan E-Learning Pada Mahasiswa Teknologi Pendidikan FIP UNY: E-Jurnal Prodi Teknologi Pendidikan Vol. VI Nomor 5 Tahun 2017. Diakses 25 februari 2018.

.Prasetya, Didik Dwi. 2015. “Kesiapan Pembelajaran Berbasis Buku Digital”, Jurnal TEKNO, Volume 24 Nomor 2: September 201560 - 64

Sitepu. 2014. Pengembangan Sumber Belajar. Jakarta: RajaGrafindo Persada.

Arifin, Anwar ,2005 Paradigma Baru Pendidikan Nasional.,Balai Pustaka, Jakarta

Email : icest@unm.ac.id. 
Azra, Azyumardi.,2012 Pendidikan Tinggi; Catatan atas Draf RUU tentang Dikti, Pointers Masukan Pada RDPU Panja Komisi X

Bandur. Agustinus., 2014 Penelitian Kualitatif Metodeologi, Desain, \& Teknik Analisis data dengan NVIVO10, Mitra Wacana Madia, Jakarta

Creswell, John W., 1998, Qualitative Inquiry and Research Design: Choosing Among Five Traditions, Sage Publications Inc. USA

Fisher, Aubrey., 1990 Teori-teori Komunikasi Perspektif Mekanistis, Psikologis, Interaksional dan Pragmatis., Remaja Rosdakarya, Bandung

Milles, M.B. and Huberman, M.A.1992: Analisis Data Kualitatif (tentang metode-metode baru), Jakarta: UI-Press.

Moleong. lexy J. 2002 Metodologi Penelitian Kualitatif, Bandung : remaja Rosdakarya

Mudlofir, Ali., 2013., Pendidik Profesional, Raja Grafindo Persada, Jakarta

Mulyana, Deddy., 2008, Ilmu Komunikasi Suatu Pengantar, Bandung, Remaja Rosdakarya

Naim, Ngainun.,2011 Dasar-Dasar Komunikasi Pendidikan, Ar-Ruzz Media, Jakarta

Saputra, hendra \& Citra Rosalyn Anwar., 2019. Buku Digital dan Sinematgrafi, Buku ajar yang Bercerita, Jurnal Komunikasi Universitas Garut Vol 5 no 1, ISSN 2461-0836 http://dx.doi.org/10.1234/jk.v5i1.592https://journal.uniga.ac.id/index.php/JK/article/view/592 Soleh, Munawar., 2007, Cita-cita Realita Pendidikan, Institute For public Education, Depok Suminar., Jenny Ratna 2010. Konstruksi Identitas Guru Professional dengan tinjauan fenomenologi Guru Professional dalam pendektan manajemen Komunikasi pendidikan . Unpad Press 